\title{
KOMPOSISI GIZI
}

\author{
DIAN YULIAWATI DARWIS
}

\section{Universitas Islam Negeri Alauddin Makassar}

Email: dianyuliawati33@gmail.com

\section{A. SUMBER ZAT GIZI}

Zat gizi adalah senyawa dari makanan yang digunakan tubuh untuk fungsi fisiologis normal. Definisi yang luas ini mencakup senyawa yang digunakan langsung untuk produksi energi yang membantu dalam metabolisme (koenzim), untuk membangun struktur tubuh atau untuk membantu dalam sel tertentu. Suatu zat gizi sangat penting untuk organisme dalam kelangsungan siklus hidup dan terlibat dalam fungsi organisme.

Berdasarkan jumlah yang dibutuhkan oleh tubuh, zat gizi terbagi ke dalam dua golongan, yaitu sebagai berikut:

1.) Zat Gizi Makro adalah makanan utama yang membina tubuh dan memberi energi. Zat gizi makro dibutuhkan dalam jumlah besar dengan satuan gram $(\mathrm{g})$. Zat gizi makro terdiri atas karbohidrat, lemak, dan protein.

2.) Zat Gizi Mikro adalah komponen yang diperlukan agar zat gizi makro dapat berfungsi dengan baik. Zat gizi mikro dibutuhkan dalam jumlah kecil atau sedikit, tetapi ada di dalam makanan. Zat gizi mikro terdiri atas mineral dan vitamin. Zat gizi mikro menggunakan satuan miligram (mg) untuk sebagian besar mineral dan vitamin.

Dalam ilmu gizi dikenal lima macam zat gizi, yaitu karbohidrat, lemak, protein, mineral dan vitamin.

1. Karbohidrat

Karbohidrat merupakan zat gizi makro yang meliputi gula, pati dan serat. Gula dan pati memasok energi berupa glukosa, yaitu sumber energi utama untuk sel-sel darah merah, otak, sistem saraf pusat, plasenta dan janin. Glukosa dapat pula disimpan dalam bentuk glikogen dalam hati dan otot, atau diubah menjadi lemak tubuh ketika energi dalam tubuh berlebih. Gula tergolong jenis karbohidrat yang cepat dicerna dan diserap dalam aliran darah sehingga dapat langsung digunakan tubuh sebagai energi. Pati termasuk jenis karbohidrat yang lama dicerna dan diserap darah, karena perlu dipecah dulu oleh enzim pencernaan menjadi gula, sebelum dapat digunakan tubuh sebagai energi, tetapi ada beberapa jenis pati yang tahan terhadap enzim pencernaan.

Sementara serat adalah jenis karbobidrat yang tidak dapat dicerna, sebab tidak dapat dipecah oleh enzim pencernaan, sehingga relatif utuh ketika melewati usus besar. Serat membantu memberikan perasaan kenyang, penting untuk mendorong buang air besar yang sehat, dan menurunkan risiko penyakit jantung koroner. 
Gula dapat ditemukan secara alami pada buah, susu dan hasil olahnya, serta dapat dijumpai dalam bentuk ditambahkan pada makanan. Pati secara alami terdapat pada beras dan hasil olahannya (bihun, tepung beras), jagung, gandum dan hasil olahannya (terigu, roti, mie), pasta, sagu, umbi-umbian (ubi, singkong, kentang), sayuran, kacang kering. Sementara serat secara alami banyak terdapat pada sereal utuh, umbi-umbian, kacangkacangan, sayuran, buah.

\section{Protein}

Protein merupakan komponen struktur utama seluruh sel tubuh dan berfungsi sebagai enzim, hormon, dan molekul-molekul penting lain. Protein dikenal sebagai zat gizi yang unik sebab menyediakan asam-asam amino esensial untuk membangun sel-sel tubuh maupun sumber energi. Karena menyediakan "bahan baku" untuk membangun tubuh, protein disebut zat pembangun.

Protein terbentuk dari asam-asam amino dan bila asam-asam amino tersebut tidak berada dalam keseimbangan yang tepat, kemampuan tubuh untuk menggunakan protein akan terpengaruh. Jika asam-asam amino yang dibutuhkan untuk sintesis protein terbatas, tubuh dapat memecah protein tubuh untuk memperoleh asam-asam amino yang dibutuhkan. Kekurangan protein memengaruhi seluruh organ dan terutama selama tumbuh kembang sehingga asupan protein kualitas tinggi yang memadai untuk kesehatan.

Kualitas protein sangat bervariasi dan tergantung pada komposisi asam amino protein dan daya cerna (digestibility). Protein hewani yang diperoleh dari telur, ikan, daging, daging unggas dan susu, pada umumnya adalah protein berkualitas tinggi. Adapun protein nabati yang diperoleh dari biji-bijian dan kacang-kacangan,pada umumnya merupakan protein berkualitas lebih rendah, kecuali kedelai dan hasil olahnya (tempe, tahu). Makanan yang tinggi daya cerna proteinnya $(>95 \%)$ ialah telur, daging sapi (98\%), susu sapi dan kedelai (95\%). Narnun, bila kacang-kacangan dan padi-padian dikonsumsi secara kombinasi, protein nabati dapat membentuk protein lebih lengkap

3. Lemak

Lemak merupakan zat gizi makro, yang mencakup asam lemak dan trigliserida. Lemak adalah zat gizi yang padat energi ( 9 kkal per gram) sehingga lemak penting untuk menjaga keseimbangan energi dan berat badan. Lemak menyediakan medium untuk penyerapan vitamin-vitamin larut lemak (vitamin A, D, E, K). Di dalam makanan, lemak berfungsi sebagai pelezat makanan sehingga orang cenderung lebih menyukai makanan berlemak. Tubuh manusia tidak dapat membuat asam lemak omega-6 dan omega-3 sehingga asam lemak ini adalah zat yang esensial

\section{Vitamin}

Vitamin adalah senyawa organik yang tersusun dari karbon, hidrogen, oksigen dan terkadang nitrogen atau elemen lain yang dibutuhkan dalam jumlah kecil agar 
metabolisme, pertumbuhan dan perkembangan berjalan normal. Jenis nutrien ini merupakan zat-zat organik yang dalam kecil ditemukan pada berbagai macam makanan . Vitamin tidak dapat di gunakan untuk rnenghasilkan energi.

Vitamin dapat dipilah menjadi 2 kelompok yaitu kelompok yang larut dalam lemak dan yang larut dalam air. Vitamin yang larut dalam lemak terdiri dari vitamin A, D, E dan K. Sedangkan vitamin yang larut dalam air terdiri dari vitamin B kompleks yang dibedakan menjadi 8 jenis vitamin yaitu vitamin B1 (Tiamin), vitamin B2 (Riboflavin), vitamin B3 (Niasin), vitamin B5 (Pantothenic Acid), vitamin B6 (Piridolasin), vitamin B7 (Biotin), vitamin B9 (Folat), vitamin B12 (Kobalamin) dan vitamin C.

5. Mineral

Mineral merupakan komponen anorganik yang terdapat dalam tubuh manusia. Sumber paling baik mineral adalah makanan hewani, kecuali magnesium yang lebih banyak terdapat dalam makanan nabati. Hewan memperoleh mineral dari tumbuhtumbuhan dan menumpuknya di jaringan tubuhnya.

Disamping itu mineral berasal dari makanan hewani mempunyai ketersediaan biologik lebih tinggi daripada yang berasal dari makanan nabati, makanan mengandung lebih sedikit bahan pengikat mineral daripada makanan nabati.

Menurut jenisnya. mineral dibedakan menjadi 2 yaitu:

a. Mineral organik, yaitu mineral yang dibutuhkan serta berguna bagi tubuh kita, yang dapat kita peroleh melalui makanan yang kita konsumsi setiap hari seperti nasi, ayam, ikan, telur, sayur-sayuran serta buah-buahan, atau vitamin tambahan.

b. Mineral anorganik, yaitu mineral yang tidak dibutuhkan serta tidak berguna bagi tubuh kita. Contohnya: timbal hitam $(\mathrm{Pb})$, iron oxide (besi teroksidasi), mercuri, arsenik, magnesium, aluminium atau bahan-bahan kimia hasil dari resapan tanah dan lain.

Berdasarkan kebutuhan tubuh mineral dibedakan menjadi 2, yaitu:

a. Mineral makro, yaitu mineral yang dibutuhkan tubuh dalam jumlah lebih dari 100 mg sehari.

b. Mineral mikro, yaitu kehutuhannya kurang dari $100 \mathrm{mg}$ sehari

\section{B. PENILAIAN STATUS GIZI LANGSUNG DAN TIDAK LANGSUNG}

Status gizi seseorang tergantung dari asupan gizi dan kebutuhannya, jika antara asupan gizi dengan kebutuhan tubuhnya seimbang, maka akan menghasilkan status gizi baik. Kebutuhan asupan gizi setiap individu berbeda antar individu, hal ini tergantung pada usia, jenis kelamin, aktivitas, berat badan ,dan tinggi badan.

Kelebihan asupan gizi dibandingkan dengan kebutuhan akan disimpan dalam bentuk cadangan dalam tubuh. Misal seseorang yang kelebihan asupan karbohidrat yang 
mengakibatkan glukosa darah meningkat, akan disimpan dalam bentuk lemak dalam jaringan adiposa tubuh. Sebaliknya seseorang yang asupan karbohidratnya kurang dibandingkan kebutuhan tubuhnya, maka cadangan lemak akan diproses melalui proses katabolisme menjadi glukosa darah kemudian menjadi energi tubuh.

Menilai status gizi dapat dilakukan melalui beberapa metode pengukuran, tergantung pada jenis kekurangan gizi. Hasil penilaian status gizi dapat menggambarkan berbagai tingkat kekurangan gizi, misalnya status gizi yang berhubungan dengan tingkat kesehatan, atau berhubungan dengan penyakit tertentu. Menilai persediaan gizi tubuh dapat diukur melalui beberapa metode penilaian:

\section{Skema Umum Pengukuran Kekurangan Gizi}

\begin{tabular}{l|l}
\hline \multicolumn{1}{c|}{ Tingkat Kekurangan Gizi } & \multicolumn{1}{c}{ Metode yang digunakan } \\
\hline Asupan zat gizi tidak cukup. & Survei konsumsi pangan \\
\hline $\begin{array}{l}\text { Penurunan persediaan gizi dalam jaringan. } \\
\text { Penurunan persediaan gizi dalam cairan } \\
\text { tubuh. }\end{array}$ & Biokimia \\
$\begin{array}{l}\text { Penurunan fungsi jaringan. } \\
\text { Berkurangnya aktivitas enzim yang } \\
\text { dipengaruhi zat gizi, terutama protein. }\end{array}$ & Antropometri atau biokimia \\
Perubahan fungsi & Biokimia atau teknik molekuler \\
Gejala klinik & Kebiasaan atau physiological \\
Tanda-tanda anatomi & Klinik \\
\hline
\end{tabular}

Gambaran cara penilaian status gizi seperti di atas, kemudian Gibson mengelompokkan menjadi lima metode, yaitu antropometri, laboratorium, klinis, survei konsumsi pangan dan faktor ekologi.

1. Metode Antropometri

Antropometri berasal dari kata anthropo yang berarti manusia dan metri adalah ukuran. Metode antropometri dapat diartikan sebagai mengukur fisik dan bagian tubuh manusia. Jadi antropometri adalah pengukuran tubuh atau bagian tubuh manusia. Dalam menilai status gizi dengan metode antropometri adalah menjadikan ukuran tubuh manusia sebagai metode untuk menentukan status gizi. Untuk mengukur status gizi adalah konsep dasar pertumbuhan.

Pertumbuhan adalah terjadinya perubahan sel-sel tubuh, terdapat dalam 2 bentukyaitu bertambahnya jumlah sel dan atau terjadinya pembelahan sel, secara akumulasi menyebabkanterjadinya perubahan ukuran tubuh. Jadi pada dasarnya menilai status gizi 
dengan metode antropometri adalah menilai pertumbuhan. Terdapat beberapa alasan kenapa antropometri digunakan sebagai indikator status gizi, yaitu:

1.) Pertumbuhan seorang anak agar berlangsung baik memerlukan asupan gizi yang seimbang antara kebutuhan gizi dengan asupan gizinya.

2.) Gizi yang tidak seimbang akan mengakibatkan terjadinya gangguan pertumbuhan, kekurangan zat gizi akan mengakibatkan terhambatnya pertumbuhan, sebaliknya kelebihan asupan gizi dapat mengakibatkan tumbuh berlebih (gemuk) dan mengakibatkan timbulnya gangguan metabolisme tubuh.

3.) Oleh karena itu antropometri sebagai variabel status pertumbuhan dapat digunakan sebagai indikator untuk menilai status gizi.

Beberapa kelebihan dan kekurangan antropometri digunakan sebagai penentuan status gizi tersebut adalah:

1.) Kelebihan antropometri untuk menilai status gizi antara lain:

a. Prosedur pengukuran antropometri umumnya cukup sederhana dan aman digunakan.

b. Untuk melakukan pengukuran antropometri relatif tidak membutuhkan tenaga ahli, cukup dengan dilakukan pelatihan sederhana.

c. Alat untuk ukur antropometri harganya cukup murah terjangkau, mudah dibawa dan tahan lama digunakan untuk pengukuran.

d. Ukuran antropometri hasilnya tepat dan akurat.

e. Hasil ukuran antropometri dapat mendeteksi riwayat asupan gizi yang telah lalu.

f. Hasil antropometri dapat mengidentifikasi status gizi baik, sedang, kurang dan buruk.

g. Ukuran antropometri dapat digunakan untuk skrining (penapisan), sehingga dapat mendeteksi siapa yang mempunyai risiko gizi kurang atau gizi lebih.

2.) Metode antropometri untuk menilai status gizi, juga mempunyai kekurangan di antaranya adalah:

a. Hasil ukuran antropometri tidak sensitif, karena tidak dapat membedakan kekurangan zat gizi tertentu, terutama zat gizi mikro misal kekurangan zink. Apakah anak yang tergolong pendek karena kekurangan zink atau kekurangan zat gizi yang lain.

b. Faktor-faktor di luar gizi dapat menurunkan spesifikasi dan sensitivitas ukuran. Contohnya anak yang kurus bisa terjadi karena menderita infeksi, sedangkan asupan gizinya normal. Atlet biasanya mempunyai berat yang ideal, padahal asupan gizinya lebih dari umumnya.

c. Kesalahan waktu pengukuran dapat mempengaruhi hasil. Kesalahan dapat terjadi karena prosedur ukur yang tidak tepat, perubahan hasil ukur maupun analisis yang keliru. Sumber kesalahan bisa karena pengukur, alat ukur, dan kesulitan mengukur. 
Beberapa contoh ukuran tubuh manusia sebagai parameter antropometri yang sering digunakan untuk menentukan status gizi misalnya:

1.) Berat Badan

Berat badan menggambarkan jumlah protein, lemak, air, dan mineral yang terdapat di dalam tubuh. Berat badan merupakan komposit pengukuran ukuran total tubuh. Beberapa alasan mengapa berat badan digunakan sebagai parameter antropometri. Alasan tersebut di antaranya adalah perubahan berat badan mudah terlihat dalam waktu singkat dan menggambarkan status gizi saat ini. Pengukuran berat badan mudah dilakukan dan alat ukur untuk menimbang berat badan mudah diperoleh

Beberapa jenis alat timbang yang biasa digunakan untuk mengukur berat badan adalah dacin untuk menimbang berat badan balita, timbangan detecto, bathroom scale (timbangan kamar mandi), timbangan injak digital, dan timbangan berat badan lainnya.

2.) Tinggi Badan atau Panjang Badan

Tinggi badan atau panjang badan menggambarkan ukuran pertumbuhan massa tulang yang terjadi akibat dari asupan gizi. Oleh karena itu tinggi badan digunakan sebagai parameter antropometri untuk menggambarkan pertumbuhan linier. Pertambahan tinggi badan atau panjang terjadi dalam waktu yang lama sehingga sering disebut akibat masalah gizi kronis.

Istilah tinggi badan digunakan untuk anak yang diukur dengan cara berdiri, sedangkan panjang badan jika anak diukur dengan berbaring (belum bisa berdiri). Anak berumur 0-2 tahun diukur dengan ukuran panjang badan, sedangkan anak berumur lebih dari 2 tahun dengan menggunakan microtoise. Alat ukur yang digunakan untuk mengukur tinggi badan atau panjang badan harus mempunyai ketelitian $0,1 \mathrm{~cm}$.

3.) Lingkar Kepala

Lingkar kepala dapat digunakan sebagai pengukuran ukuran pertumbuhan lingkar kepala dan pertumbuhan otak, walaupun tidak sepenuhnya berkorelasi dengan volume otak. Pengukuran lingkar kepala merupakan predikator terbaik dalam melihat perkembangan syaraf anak dan pertumbuhan global otak dan struktur internal.

Menurut rujukan CDC 2000, bayi laki-laki yang baru lahir ukuran ideal lingkar kepalanya adalah $36 \mathrm{~cm}$, dan pada usia 3 bulan menjadi $41 \mathrm{~cm}$. Sedangkan pada bayi perempuan ukuran ideal lingkar kepalanya adalah $35 \mathrm{~cm}$, dan akan bertambah menjadi $40 \mathrm{~cm}$ pada usia 3 bulan. Pada usia 4-6 bulan akan bertambah $1 \mathrm{~cm}$ per bulan, dan pada usia 6-12 bulan pertambahan $0,5 \mathrm{~cm}$ per bulan.

4.) Lingkar Lengan Atas (LILA)

Lingkar lengan atas (LILA) merupakan gambaran keadaan jaringan otot dan lapisan lemak bawah kulit. LILA mencerminkan tumbuh kembang jaringan lemak dan otot yang tidak berpengaruh oleh cairan tubuh. 
Ukuran LILA digunakan untuk skrining kekurangan energi kronis yang digunakan untuk mendeteksi ibu hamil dengan risiko melahirkan BBLR. Pengukuran LILA ditujukan untuk mengetahui apakah ibu hamil atau wanita usia subur (WUS) menderita kurang energi kronis (KEK). Ambang batas LILA WUS dengan risiko KEK adalah $23.5 \mathrm{~cm}$. Apabila ukuran kurang dari $23.5 \mathrm{~cm}$, artinya wanita tersebut mempunyai risiko KEK, dan diperkirakan akan melahirkan berat bayi lahir rendah (BBLR).

5.) Panjang Depa

Panjang depa merupakan ukuran untuk memprediksi tinggi badan bagi orang yang tidak bisa berdiri tegak, misal karena bungkuk atau ada kelainan tulang pada kaki. Panjang depa relatif stabil, sekalipun pada orang yang usia lanjut. Panjang depa dikrekomendasikan sebagai parameter prediksi tinggi badan, tetapi tidak seluruh populasi memiliki hubungan 1:1 antara panjang depa dengan tinggi badan. Pengukuran panjang depa juga relatif mudah dilakukan, alat yang murah, prosedur pengukuran juga mudah sehingga dapat dilakukan di lapangan.

6.) Tinggi Lutut

Ukuran tinggi lutut (knee height) berkorelasi dengan tinggi badan. Pengukuran tinggi lutut bertujuan untuk mengestimasi tinggi badan klien yang tidak dapat berdiri dengan tegak, misalnya karena kelainan tulang belakang atau tidak dapat berdiri. Pengukuran tinggi lutut dilakukan pada klien yang sudah dewasa.

Pengukuran tinggi lutut dilakukan dengan menggunakan alat ukur caliper (kaliper). Pengukuran dilakukan pada lutut kiri dengan posisi lutut yang diukur membentuk sudut siku-siku $\left(90^{\circ}\right)$. Pengukuran tinggi lutut dapat dilakukan pada klien dengan posisi duduk atau dapat juga pada posisi tidur.

7.) Tinggi Duduk

Tinggi duduk dapat digunakan untuk memprediksi tinggi badan, terutama pada orang yang sudah lanjut usia. Tinggi duduk dipengaruhi oleh potongan tulang rawan antar tulang belakang yang mengalami kemunduran, juga tulang-tulang panjang pada tulang belakang mengalami perubahan seiring dengan bertambahnya usia.

Mengukur tinggi duduk dapat dilakukan dengan menggunakan mikrotoise, dengan dibantu bangku khusus. Orang yang mau diukur tinggi duduknya, duduk pada bangku, kemudian dengan menggunakan mikrotoise dapat diketahui tinggi duduk orang tersebut.

8.) Rasio Lingkar Pinggang dan Panggul (Waist to Hip Ratio)

Lingkar pinggang menunjukkan simpanan lemak. Kandungan lemak yang terdapat di sekitar perut menunjukkan adanya perubahan metabolisme dalam tubuh. Perubahan metabolisme tersebut dapat berupa terjadinya penurunan efektivitas insulin karena beban kerja yang terlalu berat. Peningkatan jumlah lemak di sekitar perut juga dapat menunjukkan terjadinya peningkatan produksi asam lemak yang bersifat radikal bebas. 
Tingginya kandungan lemak di sekitar perut menggambarkan risiko kegemukan. Ukuran lingkar pinggang akan mudah berubah tergantung banyaknya kandungan lemak dalam tubuh. Sebaliknya, ukuran panggul pada orang sehat relatif stabil. Ukuran panggul seseorang yang berusia 40 tahun akan sama dengan ukuran panggul orang tersebut ketika berusia 22 tahun. Oleh sebab itu, rasio lingkar pinggang dan panggul (RLPP) atau waist to hip ratio (WHR) dapat menggambarkan kegemukan.

\section{Metode Laboratorium}

Penentuan status gizi dengan metode laboratorium adalah salah satu metode yang dilakukan secara langsung pada tubuh atau bagian tubuh. Tujuan penilaian status gizi ini adalah untuk mengetahui tingkat ketersediaan zat gizi dalam tubuh sebagai akibat dari asupan gizi dari makanan.

Metode laboratorium mencakup dua pengukuran yaitu uji biokimia dan uji fungsi fisik. Uji biokimia adalah mengukur status gizi dengan menggunakan peralatan laboratorium kimia. Tes biokimia mengukur zat gizi dalam cairan tubuh atau jaringan tubuh atau ekskresi urin. Misalnya mengukur status iodium dengan memeriksa urin, mengukur status hemoglobin dengan pemeriksaan darah dan lainnya. Tes fungsi fisik merupakan kelanjutan dari tes biokimia atau tes fisik. Sebagai contoh tes penglihatan mata (buta senja) sebagai gambaran kekurangan vitamin A atau kekurangan zink.

1.) Kelebihan

a. Metode laboratorium dapat mengukur tingkat gizi pada jaringan tubuh secara tepat, sehingga dapat dipastikan apakah seseorang mempunyai kadar zat gizi yang cukup atau kurang. Bahkan dalam jumlah kecil sekalipun dapat terdeteksi, seperti kekurangan iodium dalam darah.

b. Dengan mengetahui tingkat gizi dalam tubuh, maka kemungkinan kejadian yang akan datang dapat diprediksi. Dengan demikian dapat segera dilakukan upaya intervensi untuk mencegah kekurangan gizi yang lebih parah.

c. Data yang diperoleh pemeriksaan laboratorium hasilnya cukup valid dan dapat dipercaya ketepatannya.

2.) Kekurangan

a. Pada umumnya pemeriksaan yang dilakukan di laboratorium memerlukan peralatan yang harganya cukup mahal. Semakin canggih alat, maka harga akan semakin mahal, akibatnya biaya yang harus dikeluarkan untuk melakukan pemeriksaan relatif mahal.

b. Peralatan laboratorium umumnya sangat sensitif dan mudah pecah, sehingga alat laboratorium sulit untuk dibawa ke tempat yang jauh.

c. Pada waktu melakukan pemeriksaan dengan metode laboratorium, umumnya memerlukan tempat dan kondisi yang khusus agar pemeriksaan berjalan dengan baik dan aman. 
d. Batasan kecukupan zat gizi setiap individu tidak mutlak, tetapi berdasarkan kisaran. Misalnya batasan anemi bagi wanita adalah kadar hemoglobinya 12 $\mathrm{mg} / \mathrm{dl}$, tetapi ada wanita dengan kadar hemoglobin $11 \mathrm{mg} / \mathrm{dl}$ tidak menunjukkan gejala anemi.

\section{Metode Klinis}

Pemeriksaan fisik dan riwayat medis merupakan metode klinis yang dapat digunakan untuk mendeteksi gejala dan tanda yang berkaitan dengan kekurangan gizi. Gejala dan tanda yang muncul, sering kurang spesifik untuk menggambarkan kekurangan zat gizi tertentu. Mengukur status gizi dengan melakukan pemeriksaan bagian-bagian tubuh dengan tujuan untuk mengetahui gejala akibat kekurangan atau kelebihan gizi. Pemeriksaan klinis biasanya dilakukan dengan bantuan perabaan, pendengaran, pengetokan, penglihatan, dan lainnya. Misalnya pemeriksaan pembesaran kelenjar gondok sebagai akibat dari kekurangan iodium.

Pemeriksaan klinis adalah pemeriksaan yang dilakukan untuk mengetahui ada tidaknya gangguan kesehatan termasuk gangguan gizi yang dialami seseorang. Pemeriksaan klinis dilakukan dengan beberapa cara, di antaranya:

1.) Anamnesis adalah kegiatan wawancara antara pasien dengan tenaga kesehatan untuk memperoleh keterangan tentang keluhan dan riwayat penyakit atau gangguan kesehatan yang dialami seseorang dari awal sampai munculnya gejala yang dirasakan. Anamnesis dapat dilakukan dengan dua cara yaitu:

a. Auto-anamnesis yaitu kegiatan wawancara langsung kepada pasien karena pasien dianggap mampu tanya jawab.

b. Allo-anamnesis yaitu kegiatan wawancara secara tidak langsung atau dilakukan wawancara/tanya jawab pada keluarga pasien atau orang yang mengetahui tentang pasien. Allo-anamnesis dilakukan karena pasien belum dewasa (anak-anak yang belum dapat mengemukakan pendapat terhadap apa yang dirasakan), pasien dalam keadaan tidak sadar karena berbagai hal, pasien tidak dapat berkomunikasi atau pasien yang mengalami gangguan jiwa.

2.) Observasi/pengamatan adalah kegiatan yang dilakukan dengan cara melakukan pengamatan pada bagian tubuh tertentu untuk mengetahui adanya gangguan kekurangan gizi. Misalnya mengamati bagian putih mata untuk mengetahui anemi, orang yang menderita anemi bagian putih matanya akan terlihat putih tanpa terlihat arteri yang sedikit kemerahan.

3.) Palpasi adalah kegiatan perabaan pada bagian tubuh tertentu untuk mengetahui adanya kelainan karena kekurangan gizi. Misalnya melakukan palpasi dengan menggunakan kedua ibu jari pada kelenjar tyroid anak untuk mengetahui adanya pemerbesaran gondok karena kekurangan iodium.

4.) Perkusi adalah melakukan mengetukkanpada bagian tubuh tertentu untuk mengetahui reaksi yang terjadi atau suara yang keluar dari bagian tubuh yang diketuk. 
5.) Auskultasi adalah mendengarkan suara yang muncul dari bagian tubuh untuk mengetahui ada tidaknya kelainan tubuh.

Kelebihan dan kekurangan metode klinis

1.) Kelebihan metode klinis.

a. Pemeriksaan status gizi dengan metode klinis mudah dilakukan dan pemeriksaannya dapat dilakukan dengan cepat. Misal pemeriksaan anak yang odema karena kekurangan protein cukup memijit bagian kaki yang bengkak

b. Melakukan pemeriksaan status gizi dengan metode klinis tidak memerlukan alatalat yang rumit. Misalnya pada pengukuran pembesaran kelenjar gondok karena kekurangan iodium, cukup dengan menggunakan jari-jari tangan pengukur.

c. Tempat pemeriksaan klinis dapat dilakukan di mana saja, tidak memerlukan ruangan yang khusus.

d. Kalau prosedur ukur dilakukan dengan tepat, maka metode klinis menghasilkan data yang cukup akurat dalam menilai status gizi.

2.) Kekurangan metode kinis

a. Pemeriksaan klinis untuk menilai status gizi memerlukan pelatihan yang khusus setiap jenis kekurangan gizi akan menunjukkan gejala klinis yang berbeda, masing-masing harus dilakukan pelatihan yang berbeda.

b. Ketepatan hasil ukuran terkadang dapat bersifat subjektif. Terkadang pengalaman melakukan pemeriksaan mempengaruhi hasil, semakin lama pengalaman yang dimiliki, maka hasil akan semakin tepat.

c. Untuk kepastian data status gizi, terkadang diperlukan data pendukung lain, seperti data pemeriksaan biokimia. Contohnya untuk memastikan seseorang yang menunjukkan gejala anemi, perlu didukung data pemeriksaan kadar hemoglobin dari pemeriksaan biokimia.

d. Seseorang yang menderita gejala klinis kekurangan gizi, biasanya tingkat defisiensi zat gizi cenderung sudah tinggi. Misalnya seseorang yang menunjukkan adanya benjolan pada persendian kaki karena kelebihan kolesterol, maka kelebihan kolesterol dalam tubuh sudah dalam taraf yang tinggi.

e. Waktu pelaksanaan pengukuran dengan metode klinis, dipengaruhi oleh lingkungan, seperti bising, anak rewel, tebal kulit/pigmen, dan pengaruh yang lain. Misalnya sulit dilakukan pemeriksaan klinis anemi pada orang yang berkulit hitam, karena kulitnya gelap.

\section{Metode Pengukuran Konsumsi Pangan}

Ketidakcukupan asupan gizi atau kelebihan asupaan gizi dapat diketahui melalui pengukuran konsumsi pangan (dietary methode). Asupan zat gizi dari makanan yang dikonsumsi dapat mempengaruhi status gizi individu. Seseorang yang mempunyai asupan gizi kurang saat ini, akan menghasilkan status gizi kurang pada waktu yang akan datang. 
Pengukuran konsumsi makanan sering juga disebut survei konsumsi pangan, merupakan salah satu metode pengukuran status gizi. Asupan makan yang kurang akan mengakibatkan status gizi kurang. Sebaliknya, asupan makan yang lebih akan mengakibatkan status gizi lebih. Tujuan umum dari pengukuran konsumsi pangan adalah untuk mengetahui asupan gizi dan makanan serta mengetahui kebiasaan dan pola makan, baik pada individu, rumah tangga, maupun kelompok masyarakat.

1.) Kelebihan Metode Pengukuran Konsumsi Pangan

a. Hasil ukur pengukuran konsumsi pangan dapat memprediksi status gizi yang akan terjadi di masa yang akan datang;

b. Hasil pengukuran konsumsi pangan cukup akurat untuk menilai asupan gizi atau ketersediaan pangan

c. Pengukuran konsumsi pangan mudah dilakukan dengan pelatihan yang khusus;

d. Pelaksanaan pengukuran tidak memerlukan alat yang mahal dan rumit.

2.) Kekurangan Metode Pengukuran Konsumsi Pangan

a. Pengukuran konsumsi pangan, tidak dapat untuk menilai status gizi secara bersamaan, karena asupan gizi saat ini baru akan mempengaruhi status gizi beberapa waktu kemudian,

b. Hasil pengukuran konsumsi pangan, hanya dapat dipakai sebagai bukti awal akan kemungkinan terjadinya kekurangan atau kelebihan gizi pada seseorang,

c. Lebih efektif bila hasil pengukuran konsumsi pangan disertai dengan hasil pemeriksaan biokimia, klinis atau antropometri.

Pengukuran konsumsi pangan dapat dilakukan dalam tiga area, yaitu:

1.) Metode pengukuran konsumsi pangan individu

Metode pengukuran asupan gizi yang sering dipakai untuk mengukur asupan gizi pada individu, yaitu:

a. Metode recall 24-hour atau sering disebut metode recall adalah cara mengukur asupan gizi pada individu dalam sehari. Metode ini dilakukan dengan menanyakan makanan yang telah dikonsumsi dalam 24 jam yang lalu muali dari bagun tidur pada pagi hari sampai tidur lagi pada malam hari. Metode pengukuran ini bertujuan untuk mengetahui asupan zat gizi individu dalam sehari, sehingga tergolong pada kelompok metode kuantitatif.

b. Metode estiamted food record disebut juga food record atau diary record adalah metode pengukuran asupan gizi individu yang dilakukan dengan memperkiraan jumlah makanan yang dikonsumsi responden sesuai dengan catatan konsumsi makanan. Prinsip pengukuran hampir sama dengan metode recall 24 hour yaitu mencatat semua makanan yang dikonsumsi selama 24 jam, mulai dari bangun tidur pagi hari sampai tidur kembali pada malam hari.

c. Metode penimbangan makanan (food weighing) adalah metode pengukuran asupan gizi pada individu yang dilakukan dengan cara menimbang makanan 
yang dikonsumsi responden. Metode ini mengharuskan responden atau petugas melakukan penimbangan dan mencatat seluruh makanan yang dikonsumsi selama 24 jam.

d. Metode frekuensi makanan sering juga disebut FFQ (Food Frequency Quotionnaire) adalah metode untuk mengetahui atau memperoleh data tentang pola dan kebiasaan makan individu pada kurun waktu tertentu, biasanya satu bulan, tetapi dapat juga 6 bulan atau satu tahun terakhir. Terdapat dua bentuk metode frekuensi makanan yaitu metode FFQ kualitatif dan metode FFQ semi kuantitatif.

2.) Metode Pengukuran Konsumsi Pangan Rumah Tangga

Metode yang umum dipakai untuk mengukur konsumsi pangan pada tingkat rumah tangga, yaitu:

a. Metode jumlah makanan disebut juga food account method adalah metode pengumpulan data asupan makanan keluarga yang dilakukan dengan cara mencatat perkembangan bahan makanan yang masuk dan keluar selama satu periode. Semua bahan makanan yang diterima, dibeli atau produksi sendiri dicatat dan dihitung atau ditimbang setiap hari selama survei (sekitar satu minggu).

b. Metode pencatatan makanan rumah tangga adalah metode yang mengukur konsumsi makanan anggota keluarga baik di dalam rumah maupun yang makan di luar rumah. Metode ini dilakukan sedikitnya 1 minggu oleh responden sendiri atau petugas pencatat. Pengukuran dilakukan dengan cara menimbang/mengukur seluruh makanan yang ada di rumah termasuk cara mengolahnya, anggota keluarga yang makan diluar rumah juga dicatat.

c. Metode mengulang 24 jam rumah tangga (household 24-hour recall method) adalah metode pengumpulan data asupan makanan rumah tangga yang dilakukan terhadap orang yang bertanggung jawab mempersiapkan dan memasak makanan pada hari survei. Wawancara dilakukan untuk menanyakan komposisi makanan yang dimasak dan jumlah makanan yang dikonsumsi untuk jangka waktu sehari semalan (24 jam), maksimal selama 4 hari.

3.) Menilai Konsumsi Pangan pada Satu Wilayah

Menilai konsumsi pangan pada suatu wilayah dapat dilakukan dengan 2 metode, yaitu :

a. Neraca bahan makanan (NBM) atau food balance sheet adalah metode pengukuran kecukupan pangan pada suatu wlayah pada periode tertentu. Neraca bahan makanan ini dikembangkan oleh Food Agriculture Organization (FAO) dan telah digunakan oleh berbagai negara termasuk Indonesia.

b. Pola pangan harapan (PPH) adalah komposisi pangan atau kelompok pangan yang didasarkan pada kontribusi energi baik mutlak maupun relatif, yang 
memenuhi kebutuhan gizi secara kuantitas, kualitas maupun keragamannya dengan mempertimbangkan aspek sosial, ekonomi, budaya, agama dan cita rasa. 


\section{DAFTAR PUSTAKA}

1. Alam, S., \& Karini, T.A. (2020) Islamic Parenting "Pola Asuh Anak: Tinjauan Perspektif Gizi Masyarakat".

2. Almatsier, Sunita. 2010. Prinsip Dasar Ilmu Gizi. Penerbit PT. Gramedia Pustaka Utama: Jakarta.

3. Jahari Abas B. 2002. Penilaian Status Gizi dengan Antropometri (Berat Badan dan Tinggi Badan). Konggres Nasional dan Temu Ilmiah Persagi XII: Jakarta.

4. Kementerian Kesehatan RI 2010. Riset Kesehatan Dasar (Riskesdas) 2010. Badan Penelitian dan Pengembangan Kesehatan. Jakarta.

5. Kementerian Kesehatan RI. 2016. Buku Saku Pemantauan Status Gizi Tahun 2016. Direktorat Gizi Masyarakat, Ditjen Kesehatan Masyarakat. Jakarta.

6. Par'i, HM. 2016. Penilaian Status Gizi, dilengapi PAGT. Penerbit Buku Kedokteran EGC. Jakarta.

7. Fahmida.2010. Metode Penentuan Status Gizi Langsung dan Tidak Langsung. Makalah disajikan pada pelatihan Penilaian Status Gizi di Bogor, tanggal 22 November 2010.

8. Supariasa, D. Dkk. 2002. Penilaian Status Gizi. Penerbit Buku Kedokteran EGC: Jakarta. 